\title{
COMPARISON STUDY OF PKN LESSONS WITH PMP LESSONS ON THE VALUE OF DANGEROUS IN MADRASAH TSANAWIYAH MUHAMMADIYAH AIMAS SORONG DISTRICT
}

\author{
$1^{\text {st }}$ Ihsan $^{1}, 2^{\text {nd }}$ Roni Andri Pramita ${ }^{2}$ \\ \{ahmadmihsan0@gmail.com $\left.{ }^{1}, \underline{\text { ronyandry990@gmail.com }}{ }^{2}\right\}$
}

Universitas Pendidikan Muhammadiyah Sorong, West Papua, Indonesia

\begin{abstract}
Influence citizenship education in countries that embrace the concept of constitutional democracy. Many teachers are more inclined towards PMP subjects because they think that inculcation of moral values is considered successful compared to PKN because PMP has interrelated components, systematic teaching of core concepts, analysis of case studies, skills decision making skills, comparative analysis, participatory skills and citizen virtues through learning activities, the use of resource books, knowledge, skills and virtues of citizens, and linking between content and processes in teaching and learning knowledge, skills and skillscitizen-virtue. The results of efforts to realize good Indonesian citizens as expected in the 1945 Constitution, can not be separated from the constellation of the times. Based on this, the research found data and found out related to the study of PKN lesson compilation and PMP Lessons on the value of Diversity. Pancasila education lessons and citizenship decreased adolescent morality, the higher individualism of children, and more concerned with social groups that are counter to the values and norms prevailing in society compared with PMP lessons.
\end{abstract}

Keywords: citizenship, constitutional, morality, children

\section{Introduction}

Education as an element in the process of change in society, nation and state, as confirmed in the formulation of Article 3 of Law no. 20 of 2003 concerning the Education System of ability and forming the character and civilization of a dignified nation in order to educate the life of the nation "the development of the potential of students to fear God Almighty, have good morality, be healthy, have knowledge, be capable, be creative, be independent, and become citizens who will democratic and responsible ".

The formation of a dignified national character and civilization in the context of educating the life of the nation, and making human beings citizens who are democratic and responsible philosophically, socio-politically and psychopedically is a (mission sacre) of civic education (Winataputra, 2006). Furthermore, Winataputra (2006) argues that conceptually scientific, all imperatives or imperatives require a new appreciation and development of civic education as a 
scientific concept, instrumentation, and complete educational praxis. The appreciation and development in fostering civic intelligence, civic participation, and civic responsibility as Indonesian citizens and as professional educators in the field of civic education, and making citizenship education a stronger knowledge system.

Efforts to develop citizenship education as a scientific concept, instrumentation, and educational praxis are intact in line with the trends in civic education that began to be developed not only as a curricular program in schools, but also has become a scientific study, and a socialcultural citizenship movement.

Citizenship education certainly has implications in the learning process of citizenship education in schools (as subjects). Civics in schools are "subjects that focus on the formation of citizens who understand and are able to carry out their rights and obligations to become intelligent, skilled, and characterized Indonesian citizens mandated by the Pancasila and the 1945 Constitution" Year (Annex 2006 on Content Standards ). Because efforts to realize good Indonesian citizens as expected in the 1945 Constitution, can not be separated from the constellation of the times. Based on the foregoing, this study seeks to find data and find out related to PKN lesson compilation studies and PMP Lessons on Diversity values.

\section{Research Methods}

\subsection{Research Approach and Design}

In this study, researchers examined interpretatively the data from various sources about PKN lessons with PMP lessons in instilling diversity values in students, describing them thoroughly, analyzing each data that emerged, reporting the views of informants who appeared as detailed data, and do it in natural situations.

\subsection{Research Data Sources}

The type of data used in this study consists of 2 (two) sources, namely primary data and secondary data . Primary data came from informants, which include: Principal, Vice Principal Curriculum, Teachers and Users Alumni at eight schools that exist in the district Sorong,

Papua Barat. In case these researchers want to obtain information related to the tendency of teachers to subjects PMP for success in instilling the value of diversity in compare lessons PKN.

\subsection{Data Collection Techniques}

Data collection in this study uses the following techniques:

1. In- depth interview

2. Observation

3. Documentation methods. 


\subsection{Data Analysis Techniques}

First, qualitative descriptive analysis techniques, according to Miles and Habermas (in Sugiyono, 2011), suggest that activities in qualitative data analysis are interactive and take place continuously until the data feels saturated. Qualitative descriptive analysis technique used continuously looking for the planting of the value of diversity that has been collected by researchers from a variety of sources, systematically carried out the data analysis includes the following steps: (a) the reduction of the data (data reduction); (b) data presentation or data display ; (c) drawing conclusions or data verification.

Second, domain analysis. In the domain analysis the information obtained is not exhaustive, still on the surface but has found the domains or categories of the social situation under study (Sugiyono, 2007: 101). Domain or factor-factors associated in this study are the internal factors ( factors that support and hinder terkaid that teachers at PMP in comparison Civics Lesson in penenman value of diversity in students) and external factors (factors that support and hinder Civics in penenaman value of diversity in student).

\subsection{Data Validity Test}

In the process of checking and validity of the data used data validity checking techniques (triangulation). Trianggulation is defined as checking data from various sources, in various ways and at various times. While this type of triangulation are used include: (a) triangulation of data sources, carried out by way of checking the data that has been obtained through several sources; (b) technical triangulation, carried out by checking the data to the same source with different techniques Moleong (2010: 30), The validity of the data in this study.

\section{Research Results}

Learning implies that each activity is designed to help someone learn a new ability or value. The learning process initially asks the teacher to know the basic abilities possessed by students including their basic abilities, motives, academic background, socio-economic background, and so on. Teacher readiness to recognize the characteristics of students in learning is the main capital for the delivery of teaching materials and an indicator of success in the implementation of learning. The importance of social skills will greatly affect the character of students, by having good skills they can communicate effectively and efficiently with the surrounding environment. Social skills are manifested in the behavior of student activities, these activities emphasize the formation of student character. These characters are those who are able to regulate and manage emotions, because at this age their emotions are volatile so there is a need for direction and guidance. The same reality also occurs in MTs Muhammadiyah Aimas Sorong Regency, learning here is the process of interaction of students with educators and learning resources in a learning environment.

Learning is an assistance given by educators so that the process of acquisition of knowledge and knowledge, mastery of skills and character, and the formation of attitudes and beliefs in 
students. In other words, learning is a process to help students to be able to learn well. The importance of implementing good learning will greatly affect student learning outcomes, and therefore there needs to be good coordination of all elements of the school to manage and regulate the learning process so that it can run smoothly according to the expected curriculum. The coordination is the result of communication between the school principal and teachers to overcome various obstacles that arise in the implementation of learning. At MTs Muhammadiyah Aimas, good communication is always maintained by the Principal with other teachers. Implementation of learning in schools can run in accordance with the school curriculum certainly requires the role of the vice principal in the field of curriculum. Wow The curriculum which has the task of supervising the application of the curriculum runs optimally, arranging teacher assignments and learning schedules, and fostering competition activities in schools having a strategic role in terms of evaluation and in terms of monitoring the implementation of the curriculum.

Madrasah Tsanawiyah Muhammadiyah Aimas Sorong Regency in implementing the school curriculum runs smoothly. Citizenship education is one of the subjects in the school, which has the task of forming good citizens. A good citizen is a person who has a spirit of tolerance and tolerance among fellow citizens. The goal is to realize that citizens are aware of national defense based on national political understanding, sensitivity to develop national identity and morals in the life of the nation. Based on this, learning citizenship education at MTs Muhammadiyah Aimas is developing learning not only in the classroom. But also through various activities outside the classroom and outside the school. Because the standard in citizenship education lessons is Diversity Value. The importance of citizenship education lessons for students to learn, this is due to the decline in adolescent morality, the higher individualism of children, and more concerned with social groups that are counter to the values and norms prevailing in society.

\section{Research Discussion}

With the enactment of Law Number 2 of 1989 concerning the National Education System which outlines the content of the Pancasila Education and Citizenship Education curriculum, as compulsory study material for all paths, types and levels of education (Article 39), the 1994 Basic Education and Secondary Education Curriculum accommodates the new mission of education is by introducing the subjects of Pancasila and Citizenship Education or PPKn. In contrast to the previous curriculum, the 1994 PPKn curriculum organized learning material not on the basis of the P4 value points, but on the basis of the value concepts that were drawn from P4 and other official sources that were arranged using a broad spiral approach or spiral of concept development (Taba, 1967 ). This approach articulates the Pancasila precepts with their values for each level of education and class and quarterly chess in each class.

Conditions and situations the United States has experienced. Since its birth in the 1880s, several terms have been used interchangeably, such as the terms " Civics, Civic / Citizenship Education, Social Studies / Social Science Education " until the publication of the NCSS academic document (1994), namely "Curriculum for Social Stand Studies: Expectations of Excellence " Stay in bikini, crisis . conceptual and curricular in the United States, has been successfully 
overcome. At least they have now reached an academic and programmatic consensus which in turn will lead to a more coherent curriculum process .

In an effort to seek agreement, which if possible could give birth to "curriculum like standards" The development of thinking about citizenship education in Indonesia from the Proclamation of August 17, 1945 to 1999 as the end point of the 20th century. It can be seen from the ideals, concepts, values, a concept that is conceptually explicit and or implicit in various official documents, which indeed is a pillar of Indonesia's national education, as outlined in the book "Lim of Indonesian Education" (Djojonegoro: 1996 since 1995 until now. While citizenship education according to Cogan (1998) ). the assertion about the purpose and the mission are consistently maintained in various official documents relating to education in Indonesia.

The situation turned out to continue until the change of the 1984 PMP Curriculum into the Pancasila and Citizenship Education Curriculum (PPKn) in 1994, which although its name includes a study of Pancasila education and citizenship education in accordance with Law No. 2 of 1989 , but its curricular characteristics are very thick with moral education Pancasila, which is dominated by the process of value inculcation and knowledge dissemination. This can be seen from the 1994 PPKn curriculum profile, which shows the following characteristics (Depdikbud, 1993).

First, the SD PPKn aims to instill attitudes and behaviors in daily life that are based on Pancasila values. Meanwhile in junior high school, PPKn aims to develop knowledge and ability to understand and live the values of Pancasila in the context of forming attitudes and behaviors.

Second, learning materials are developed based on the points of value concepts that are included in each of the Pancasila precepts, then are organized in an artistic manner between chess players at each class and level (elementary, junior high, high school). The spiral curriculum approach, Taba's (1967) spiral of concept development seems to be applied strictly to the achievement of the principles of continuity, integration, and articulation (Tyler, 1949).

Third, because of the strict application of the principles of articulation in the organization of learning materials, and by referring to points of value.

PPKn 1994 curriculum, the paradigmatic nuances of civic education have not been felt. Therefore it can be said that the 1994 PPKn, paradigmatically, is actually the same as the PMP before. Or in other words, Pancasila Education still acts as its core or concerto, with Citizenship Education as one of its accompanyments. From there it can be understood, why intelligent and religious democratic behavior, which is characteristic of civic education in civil society, has not yet fully developed in Indonesian nation-society .

From the development of citizenship education in Indonesia to the present, it can be said that both at the conceptual level and at the practical level there are fundamental paradigmatic weaknesses. The most prominent are weaknesses in the conceptualization of civic education, excessive emphasis on behavoristic moral education processes, inconsistency in the elaboration of dimensions of national education objectives into the civic education curriculum, and isolation of the learning process of Pancasila values with the context of scientific and socio-cultural disciplines. 


\subsection{The tendency of PMP lessons in instilling diversity}

It is certain that there is almost no country in the world that can live without contact with other nations (Azis Wahab, 2006). Interdependence theory increasingly shows the truth. That means that citizens prepared through citizenship education in schools must be equipped with themes other than dependence, also about cultural change, scarcity and conflict. All the themes in teaching should senantia sa viewed in the context of the global with emphasis on issues and problems of the local.

In the above framework, the need to equip citizens with a global understanding, becomes inevitable in Citizenship Education to develop global citizenship. Therefore, Adult Citizenship Education needs to pay attention to the global trends that occur that inevitably affect Citizenship Education.

Azis Wahab (2006: 63-64) suggests some influential global trends in Citizenship Education, as follows: Failure to apply the concept of past civic education, as a result and emphasis on truth which is monovision and completely ignores the possibility of multivision or if it is done it only changes semupoliti system; 2) which is more directed towards reform efforts in various fields of life both social and cultural, politics itself, economics and law which are mandatory in both the primary and secondary education curriculum and the higher education curriculum (Article 37). 3) Changes to the global trend towards a global citizenship education for democracy.

The global trend above affects the development of new concepts and paradigms of Civic Education, including for the development of citizens who have a global perspective.

\subsection{Citizenship Education in Schools}

As stated before, that historically, the Civics Education curriculum has fluctuated, especially in the naming and content of the material. First appeared as Citizenship (1957), Civics (1961), National Citizenship Education (1968), Pancasila Moral Education (1975), Pancasila and Citizenship Education (1994), Citizenship (Curriculum Trial 2004) and finally under the name Citizenship Education (2006).

In Law No. 20 of 2003 concerning the National Education System emphasized that compulsory citizenship education study material is included in both the primary and secondary education curriculum and the higher education curriculum (Article 37). The provision of Citizenship Education in the Law on the National Education System as a compulsory subject at the level of primary, secondary, and higher education shows that these subjects occupy a strategic position in achieving national education goals. At the level of SMP / MTs citizenship education subjects are subjects that focus on the formation of citizens who understand and are able to carry out their rights and obligations to become smart, skilled, and characterized Indonesian citizens mandated by Pancasila and the 1945 Constitution (Permendiknas No 22 of 2006).

The aim of Citizenship Education is that students have the ability: (1) Think critically, rationally, and creatively in responding to the issue of citizenship Participate actively and responsibly, and act intelligently in community, national and state activities, and anti-corruption , (2) Developing positively and democratically to form themselves based on the characteristics of Indonesian society so that they can live together with other nations (3) Interact with other nations in the world directly or indirectly by utilizing information and communication technology . (Permendiknas No. 22 of 2006) 
While the scope of Citizenship Education material in accordance with the 2006 curriculum is: (1). National Unity and Unity, (2). Norms, laws and regulations, (3). Human rights, (4). Needs of citizens, the State Constitution, (5). Violence and Politics, (6). Pancasila, (7). Globalization. (Permendiknas No. 22 of 2006) The seven scope of Citizenship Education material in the 2006 Curriculum is further broken down into Basic Competency and Competency Standards.

\section{Conclusion}

Based on the results of the study it can be concluded that the effort to realize good Indonesian citizens as expected in the 1945 Constitution, cannot be separated from the constellation of the times. Based on this, the research found data and found out related to the study of PKN lesson compilation and PMP Lessons on the value of Diversity. Pancasila education lessons and citizenship decreased adolescent morality, the higher individualism of children, and more concerned with social groups that are counter to the values and norms prevailing in society compared with PMP lessons.

\section{Reference}

[1] Azis Wahab , A. (1996) . " Politics of Indonesian Citizenship Education Education towards Wargane Speech inauguration of permanent professorship in Education at the Department of Moral Education in Pancasila, Citizenship and Law FPIPS IKIP Bandung. October 18, 1996

[2] Azis Wahab , A. (2006). Development of Concepts and Paradigms of Indonesian New Citizenship Education for the Establishment of Indonesian Multidimensional Citizens. In Budimansyah, Dasim and Syaifullah ( ed ). Moral Value Education in the Dimension of Citizenship Education (Welcoming 70 years of Prof.Drs.HA Kosasih Djahiri). Bandung: Lab. FPIPS UPI.

[3] Cogan, John J and Ray Derricot. (1998). Citizsenship for the $21^{\text {st }}$ Century: An International Perspective of Education . London: Kogan Page.

[4] Creswell, John W. (1998). Qualitative Inquiry and Research Design: Choosing Among Five Traditions . London: Sage Publications.

[5] Ministry of Education. (2003). Curriculum 2004: Competency Standards for Subjects in Citizenship Education . Jakarta: Ministry of National Education Republic of Indonesia.

[6] Djojonegoro, W. (1996). Fifty Years of Indonesian Education. Jakarta: Balai Pustaka.

[7] Neuman, W. Lawrence (2000), Social Research Methods: Qualitative and Quantitative Approaches, $4^{\text {th }}$ edition, Allyn \& Bacon, Boston.

[8] Moleong, Lexy J. (2007). Qualitative Research Methodology. Bandung: Teen Rosdakarya,

[9] Sugiyono (2007). Statistics for Research . Bandung: Alfabeta

[10] Sugiyono (2011). Quantitative, Qualitative, and R\&D Research Methods . Bandung: Afabeta

[11] Taba, H., Durkin MC., Fraenkel, JR. and McNaughton, AH. (1971). A Teacher's Handbook of Elementary Social Studies: An Inductive Approach. Reading: Addison Wesley.

[12] Tyler, RW. (1975). Basic Principles of Curriculum and Instruction. Chicago: The University of Chicago Press.

[13] Winataputra, US 2006. Democracy and Democracy Education. Jakarta: Directorate General of Higher Education 